\title{
Response to Technological Modernization of Banking Facilities in Rural India
}

\author{
J. Kannan, D. Venkatrama Raju
}

\begin{abstract}
The Banking scheme of India must not only be disturbed free except it ought to be proficient to assemble latest challenges posed by the knowledge and any other outside and interior factors. E-Banking has a lot of reimbursement that adds worth to customer's happiness in conditions of improved feature of service aid and at the similar occasion allow, the banks increase additional spirited benefit above new competitors. E-Banking services includes like, portable banking, online banking, ATM (Automated Teller Machine), DCM (Cash Deposit Machine), RTGS (Real Time Gross Settlement), NEFT (Net Electronic Fund Transfer), and Tele Banking.
\end{abstract}

Keywords : E-Banking, NEFT, Tele Banking

\section{INTRODUCTION}

Electronic banking is a sunshade word for the practice by which a customer may achieve banking dealings automatically with no visiting a element and mortar institution. The examiner has conceded out the research job in arrange to identify how banks are delivering e-banking services via the superior knowledge and also aims to convey to the publicity the benefits linked with e-banking services and evils also[1]-[4]. The mobile phone have apparently never-ending potential and the banking industry in revolve has determined to it won't exist left after it in capitalizing the opportunity provided by mobile services in its company. Marvelous development in the meadow of information expertise has compact the earth to a universal community and it has caused unparalleled modify in the banking industry. The expansion and the mounting development that is mortal practiced in sequence and announcement knowledge have brought regarding a lot of changes in nearly all facets of life. It has been in the structure of E-Banking, which is now replacing the established banking carries out.

\section{SCOPE OF THE STUDY}

The learning was restricted to the clients availing cell phone services of Banks. It be based on diverse aspects of customers' discernment concerning goods and services of

Revised Manuscript Received on December 11, 2019

J. Kannan, Department of Science and Humanities, Bharath Institute of Higher Education and Research, Chennai , India. Email sjkannan1986@gmail.com

D. Venkatrama Raju, Department of Science and Humanities, Bharath Institute of Higher Education and Research, Chennai, India. Email: prof.dvraju@gmail.com banks. Range of the learn not only consist one or two prospect commerce arrangement except for a moment it also gives thought regarding a new business which becomes a large amount additional gainful for the research then the elder one. It too gives the predictable situation for a fresh winning policy through a correct accomplishment plan[5].

\section{A. Objective}

$>$ To recognize age wise and profession wise customers who prefer E-Banking services

$>$ To establish usage and reasons for preferring e-banking services

\section{B. Hypothesis}

$>$ There is no relationship between Age and aware of being provided through the internet banking.

$>$ There is no relationship between Gender and prefer the most to take from the bank.

\section{RESEARCH METHODOLOGY}

Methodology is defined as the requirement of methods and measures for acquiring the information needed. It is a arrangement contained by which the investigate has been undertaken.

\section{A. Method of sampling}

Sampling is a procedure of obtaining the in sequence concerning a complete population with probing merely a fraction of it. The investigator has used the Convenience sample technique and chosen 140 customers for the review[6]-[9].

\section{B. Source of data}

Both the primary data and the secondary data are taken into explanation for the point of the study.

\section{Statistical tool}

Different statistical tools used for the analysis of data. They are percentage analysis, Chi-Square test.

\section{Limitation of the study}

The information from the model may not replicate 


\section{Response to Technological Modernization of Banking Facilities in Rural India}

the world; because it is limited merely to the area of Chennai City and only 140 customers. There was also time limitation.

\section{E. Method of Sampling}

Sampling is a process of obtaining the information about an entire population by examining only a part of it. For the purpose of this study the researcher has used the Convenience sampling method and selected 100 customers randomly for the survey.

\section{RESULTS AND DISCUSSIONS}

$>40 \%$ of the respondents are age in between 26-35 Years.

$>50 \%$ of the respondents are male and female[10]-[14].

$>70 \%$ of the respondents Educational Qualification are PG degree.

$>55 \%$ of the respondent occupations are services.

$>40 \%$ of the respondents income level in between Rs. 15,000-Rs.25,000.

$>70 \%$ of the respondents maintaining bank account in Indian Bank.

$>90 \%$ of the respondents are maintained Savings account in banks.

$>63 \%$ Rank 1 withdraw of cash

$>56 \%$ Rank 1None of the above

$>65 \%$ of the respondents provided services the mobile banking are a/c balance any time

$>50 \%$ of the respondents prefer the most to take from the bank are Gold loan.

$>60 \%$ of the respondents no draw backs in the services.

$>35 \%$ of the respondents e-booking as a new system delivering banking services are cannot say exactly.

$>85 \%$ of the respondents are aware about E-banking services[15]-[19].

$>35 \%$ ATM Rank 1\& 3 obtained ATM banking.

$>42 \%$ of the respondent Rank $1 \& 3$ obtained Fund transfer

$>35 \%$ of the respondents know about E-banking services are through their employers.

$>40 \%$ of the respondents agree that through bank official advertisement in print media is the major services are highly agree

$>35 \%$ of respondents are agreed that E-banking services at cost effective.

$>55 \%$ of the respondents are highly agreed that e-banking services are highly agree

$>45 \%$ of the respondents agree that E-banking services are easy to use in nature[20].

\section{SUGGESTIONS}

Bankers should create awareness about the usage of e-banking services provided to the customers.

$>$ The Customer relationship manager should perform effectively to clear complaints made by the customer then and there.
$>$ Try to reduce fear about e-banking services.

$>$ Bankers also educate to the customers about the significance of e-banking services[21]-[23].

$>$ E-banking servicers reduce time but increase the cost. So bankers try to reduce cost also.

$>$ E-banking services will make it as user friendly.

$>$ Updating the latest strategies and security measures in addition to blanked measures for E-banking should be implemented appropriately[24].

$>$ The number of e-banking centers has been increased according to the basis of necessary.

$>$ Banker's charges should be minimized to e-banking users.

$>$ To provide effective advertisement for using e-banking facilities by the customers effectively[25].

\section{CONCLUSION}

It is very evident that, e-banking administrations have become an acknowledged standard of money related exchanges for many clients in Chennai city and unquestionably, a correct more to give accommodation to the client just as the financiers. The simplicity with which a client can check his record, make online installments, make mistake free exchanges, economy in costs, decrease in time spent in doing business exercises, lessen blockage in banking corridors, improve conveyance framework and fast move cash between records has made this method of banking enormously prevalent among Indians who are interminably shy of time to visit the bank premises physically. E - banking likewise gives a large group of non-value-based highlights, which are very convenient to the client. Be that as it may, alongside the universe of comforts this technique for banking has a couple of inborn traps, which should be comprehended so as to ensure the enthusiasm of the clients and their cash to destroy entanglements thusly.

\section{REFERENCES}

1) Vasanthi, S. \& Rabiyathul Basariya, S. 2019, "Influence of value analysis and cross training in industry", International Journal of Engineering and Advanced Technology, vol. 8, no. 6, pp. 1810-1811.

2) Velvizhi, R., Sri Gowtham, S. \& Jeya Priya, D. 2019, "Examination of early feedbacks for effective product retailing on E-commerce websites", International Journal of Engineering and Advanced Technology, vol. 8, no. 6 Special Issue 2, pp. 703-706.

3) Anuradha, C., Pothumani, S. \& Kavitha, R. 2019, "A novel method towards E-commerce", International Journal of Engineering and Advanced Technology, vol. 8, no. 6 Special Issue 2, pp. 535-538.

4) Thomas, J. \& Rabiyathul Basariya, S. 2019, "A study on the issues of financial ratio analysis", Indian Journal of Public Health Research and Development, vol. 10, no. 3, pp. 1079-1081.

5) Ramachandran, S. \& Rabiyathul Basariya, S. 2019, "Online marketing study on customer satisfaction and relationship", Indian Journal of Public Health Research and Development, vol. 10, no. 3, pp. 1072-1078.

6) Priya, R., Vinothini, G. \& Cor Jesu, C.D. 2019, "The mentor-protégé relationship for professional growth", Journal of Advanced Research in Dynamical and Control Systems, vol. 11, no. 9 Special Issue, pp. 1110-1119.
Blue Eyes Intelligence Engineering \& Sciences Publication 
7) Jannifer Rani, N., Bina Pani, S. \& Nimisha, N.S. 2019, "A study on money back polices available in LIC", Journal of Advanced Research in Dynamical and Control Systems, vol. 11, no. 9 Special Issue, pp. 833-839.

8) Saillaja, V., Jhansi Rani, K. \& Catherine, R. 2019, "Global marketing management planning and organization", Journal of Advanced Research in Dynamical and Control Systems, vol. 11, no. 9 Special Issue, pp. 489-493.

9) Saillaja, V., Jhansi Rani, K. \& Catherine, R. 2019, "The new phase of marketing information system", Journal of Advanced Research in Dynamical and Control Systems, vol. 11, no. 9 Special Issue, pp. 482-488.

10) Thoufiqulla \& Raju, D.V. 2019, "Perception of indian investor towards investment in mutual funds with special reference to mip funds", Journal of Advanced Research in Dynamical and Control Systems, vol. 11, no. 5, pp. 177-183.

11) Jasmine, K.R.M. \& Basariya, S.R. 2018, "A study on the customers benefits on mutual funds", International Journal of Civil Engineering and Technology, vol. 9, no. 4, pp. 45-48

12) Vasanthi, S. \& Basariya, S.R. 2019, "Pros and cons of on the job training versus off the job training", International Journal of Scientific and Technology Research, vol. 8, no. 10, pp. 671-674.

13) Pavithra, J. \& Ganesan, M. 2016, "A study on awareness and impact of micro-financial schemes", International Journal of Applied Business and Economic Research, vol. 14, no. 8, pp. 5449-5460.

14) Pavithra, J., Dilli Babu, P. \& Ambuli, T.V. 2014, "A study on budgetary control at Maruti Service Masters, Chennai", International Journal of Applied Business and Economic Research, vol. 12, no. 2, pp. 151-161.

15) Gunaraja, T.M. \& Venkatrama Raju, D. 2018, "Determining factors of organisational climate with reference to leadership styles", International Journal of Mechanical Engineering and Technology, vol. 9, no. 9, pp. 1327-1332.

16) Gunaraja, T.M. \& Venkatrama Raju, D. 2018, "The role of job satisfaction and training of employees in determining organisational climate of a selected industry", International Journal of Civil Engineering and Technology, vol. 9, no. 8, pp. 1266-1269.

17) Aarathy, T.S. \& Raju, D.V. 2018, "Performance appraisal and its effects on employees with respect to it sector in Chennai city", International Journal of Civil Engineering and Technology, vol. 9, no. 6, pp. 1535-1538.

18) Aarathy, T.S. \& Raju, D.V. 2018, "Employee perception towards performance appraisal system in IT sector", International Journal of Mechanical Engineering and Technology, vol. 9, no. 5, pp. 131-135.

19) Porselvi, W., Jublee, D. \& Sivanesan, G. 2018, "A study on factors influencing adoption of technology and innovation in banking industry, tamilnadu, India", International Journal of Mechanical Engineering and Technology, vol. 9, no. 5, pp. 789-800.

20) Akessa, G.M. and Dhufera, A.G., 2015. Factors That Influences Students Academic Performance: A Case of Rift Valley University, Jimma, Ethiopia. Journal of Education and Practice, 6(22), pp.55-63.

21) Miller, G. and Shih, C.C., 1999. A faculty assessment of the academic rigor of on-and off-campus courses in agriculture. Journal of Agricultural Education, 40, pp.57-65.

22) Tsinidou, M., Gerogiannis, V. and Fitsilis, P., 2010. Evaluation of the factors that determine quality in higher education: an empirical study. Quality Assurance in education, 18(3), pp.227-244.

23) Farooq, M.S., Chaudhry, A.H., Shafiq, M. and Berhanu, G., 2011. Factors affecting students' quality of academic performance: a case of secondary school level. Journal of quality and technology management, 7(2), pp.1-14.

24) Fitsilis, P., Gerogiannis, V. and Anthopoulos, L., 2014. Ontologies for software project management: a review. Journal of Software Engineering and Applications, 7(13), p.1096.

25) Adams, J.D. and Jaffe, A.B., 1996. Bounding the effects of R\&D: an investigation using matched establishment-firm data(No. w5544). National bureau of economic research.

\section{AUTHORS PROFILE}

J. Kannan Associate Professor, Department of Science and Humanities, Bharath Institute of Higher Education and Research, Chennai, India.

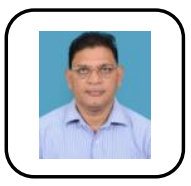

D. Venkatrama Raju Professor, Department of Science and Humanities, Bharath Institute of Higher Education and Research, Chennai, India. 